\title{
Calcium-activated Release of Nitric Oxide and Cellular Distribution of Nitric Oxide-Synthesizing Neurons in the Nervous System of the Locust
}

\author{
Uli Müller and Gerd Bicker \\ Institut für Neurobiologie, 14195 Berlin, Germany
}

Nitric oxide (NO) is generated by a $\mathrm{Ca}^{2+} / \mathrm{calmodulin-acti-}$ vated NO synthase and diffuses as a short-lived transcellular messenger through the plasma membrane. This study investigates the neurochemistry and anatomical distribution of NO-releasing cells in the CNS of the locust. $\mathrm{Ca}^{2+} / \mathrm{Cal}$ modulin-activated NO synthase is responsible for fixationinsensitive NADPH diaphorase (NADPHd) activity in cell homogenates of the nervous system. Therefore, neurons expressing NO synthase were detected by NADPHd histochemistry performed in whole-mounts. The anatomical screening revealed fewer than $1 \%$ NADPHd-positive cells in the ventral nerve cord, some of which were single potentially identifiable neurons, and groups of cell bodies in several regions of the cerebral ganglion. A prominent feature of the histochemical survey in the cerebral ganglion is a group of $\mathbf{4 5}$ intensely stained cells innervating the olfactory neuropil of the antennal lobe.

A basic requirement for identifying NO as a messenger molecule is the $\mathrm{Ca}^{2+}$-dependent release during nerve cell depolarization. With a sensitive photometric assay we demonstrated that dissociated cells from brain areas rich in NADPHd-positive neurons release NO after stimulation by agents elevating cytoplasmic $\mathrm{Ca}^{2+}$ levels and by the excitatory neurotransmitter acetylcholine. The combined anatomical and biochemical experiments therefore provide firm evidence that NO is a messenger molecule released in the CNS of the locust. Since locust neurons can be readily grown in primary culture, NO-induced elevations of CGMP levels and other signal transduction mechanisms in target cells will also be amenable to a cellular analysis.

[Key words: NADPH diaphorase, NO synthase, transmitter release, olfactory neuropil, signal transduction]

There is increasing evidence that insect nervous systems use nitric oxide (NO) as a chemical messenger. Biochemical assays have demonstrated the presence of $\mathrm{Ca}^{2}+$ /calmodulin-activated NO synthase and NO-activated guanylyl cyclase in homogenates of locust brain (Elphick et al., 1993). The biochemical properties

\footnotetext{
Received Jan. 26, 1994; revised May 24, 1994; accepted June 1, 1994

We thank Hans-Jochen Pflüger for providing us with the experimental animals, Christine Jaeckel for technical assistance, and Malcolm Burrows for comments and help with the manuscript. This work was supported by a grant from the Deutsche Forschungsgemeirıschaft to the Forschergruppe Lernen, Gedächtnis und Neuromodulation in Arthropoden, and a Heisenberg Fellowship to G.B.

Correspondence should be addressed to Drs. Uli Müller and Gerd Bicker, Institut für Neurobiologie, Königin-Luise-Strasse 28-30, 14195 Berlin, Germany.

Copyright (C) 1994 Society for Neuroscience 0270-6474/94/147521-08\$05.00/0
}

of NO synthase have also been characterized with the sensitive oxyhemoglobin assay (Feelisch and Noak, 1987; Murphy et al., 1991; Mayer et al., 1992) in the brain of Drosophila and Apis (Müller, 1994), showing that in both species NO synthase activity and NADPH diaphorase (NADPHd) activity after fixation are caused by identical enzymes. Furthermore, measurements of NO synthase activity in homogenates of the various neuropils correlated well with the histochemical staining pattern for NADPHd (Müller and Buchner, 1993; Müller, 1994). As in vertebrates (Dawson et al., 1991; Hope et al., 1991; Vincent and Kimura, 1992), NO synthase-expressing cells of insect nervous systems can be reliably identified by NADPHd histochemistry.

Werman (1966) has formalized the experimental approaches needed to establish whether a given substance is functioning as a neurotransmitter in the nervous system. Briefly, these requirements can be summarized as presence, synthesis, release, inactivation, identity of action, and reception. One of the criteria for transmitter identification that in practice is difficult to prove is the calcium-dependent release following depolarization of neurons. Obviously, the identification criteria of Werman (1966) were formulated for conventional neurotransmitters released in a calcium-dependent process from synaptic vesicles. Nevertheless, there are clear formal parallels to the generation and reception of unconventional messenger molecules like NO. After their $\mathrm{Ca}^{2+}$-activated production catalyzed by NO synthase, the short-lived NO molecules are thought to diffuse through the plasma membrane as a transcellular messenger and stimulate the guanylyl cyclase of adjacent cells (reviews: Garthwaite, 1991; Bredt and Snyder, 1992). It would therefore be advantageous to work with a preparation in which the complete chain of events from plasma membrane depolarization to NO release onto defined target cells can be studied. The objective of our study was to identify candidate insect neurons that would allow the demonstration of a $\mathrm{Ca}^{2+}$-stimulated NO release.

The nervous system of the locust is built on a clearly segmented plan containing many neurons that can be reliably identified from one animal to another. Since adult and larval locust neurons can be readily kept in primary cell culture (Giles and Usherwood, 1985; Kirchhof and Bicker, 1992), it should also be possible to investigate the cellular responses to NO exposure in a controlled environment. Hence, we have analyzed the nervous system of the locust, a commonly used neurobiological preparation, for NADPHd activity.

This article addresses three issues. First, we provide a survey of the anatomical distribution of NO-producing cells in the brain and segmental ventral ganglia of the locust by NADPHd his- 
tochemistry. The histochemical staining revealcd groups of ncurons in the brain and single identifiable neurons in the ventral nerve cord that are candidates for releasing NO. Second, we show that certain dissociated neurons express the NADPHd phenotype. NADPd and NO synthase activity show a ratio of one in cell homogenates from various parts of the nervous system, indicating the identity of the enzyme. Finally, we demonstrate that dissociated cells obtained from brain areas rich in NADPHd-positive neurons release NO after stimulation by agents that elevate cytoplasmic $\mathrm{Ca}^{2+}$ levels. The combined anatomical and biochemical experiments provide firm evidence that NO is a messenger molecule acting in the CNS of the locust. Furthermore, the presence of NO synthase and NO-stimulated guanylyl cyclase in brain homogenates (Elphick et al., 1993) and our demonstration of a calcium-activated NO release from dissociated neurons indicate that the nervous system of the locust is an accessible invertebrate preparation to study NO signal transduction.

\section{Materials and Methods}

Experiments were performed on Schistocerca gregaria reared in a crowded colony by $\mathbf{H}$. J. Pflüger's research group at our institute. All reagents, salts, and solvents were of analytical grade and were obtained from Sigma, GIBCO, or Boehringer.

NADPH diaphorase histochemistry. Locusts were chilled on ice and parts of the nervous tissue including the cerebral ganglion and the ventral nerve cord were dissected. After careful removal of connective tissue surrounding the ganglia, the tissues were fixed in $4 \%$ paraformaldehyde in PBS for $2 \mathrm{hr}$ at $4^{\circ} \mathrm{C}$ followed by washes in PBS. For permeabilization, the tissues were incubated overnight in PBS containing 0.5\% Saponin at $4^{\circ} \mathrm{C}$. After washing with PBS the visualization of fixation-insensitive NADPH diaphorase activity was performed by incubation of the tissues in $50 \mathrm{~mm}$ Tris- $\mathrm{HCl}, \mathrm{pH} 7.8,0.1 \%$ Triton $\mathrm{X}-100$, and $0.1 \mathrm{~mm}$ nitro bluc tetrazolium in the presence or absence of $0.1 \mathrm{~mm} \beta-\mathrm{NADPH}$ at $25^{\circ} \mathrm{C}$ for $60-90 \mathrm{~min}$. After termination of staining the tissues were washed in PBS and mounted in PBS:glycerol 1:9. A similar procedure with the exception of the permeabilization step was applied to cultured cells

Cell culture. Details of the dissection of the locusts and the establishment of primary cell cultures have been described in detail elsewhere (Kirchhof and Bicker, 1992). Briefly, the cerebral ganglion and the three thoracic ganglia $(\mathrm{tg})$ were dissected under a sterile Leibovitz L-15 medium (GIBCO) containing $50 \mu \mathrm{g} / \mathrm{ml}$ gentamicin. After removal of the optic lobes the central brain (br) and the antennal lobes (al) were separated. The tissues were enzymatically treated with collagenase/dispase (Boehringer) according to the protocol of Kirchhof and Bicker (1992). After dissociation, cells were used for experiments on the same day or cultured for a week to allow for ncurite outgrowth.

NO synthase activity of cell homogenates. The dissociated cells of the central brain (br), the antennal lobe (al), and the thoracic ganglia (tg) of four experimental animals of larval stage 5 were homogenized in 100 $\mu \mathrm{l}$ of $50 \mathrm{~mm}$ Tris- $\mathrm{HCl}, \mathrm{pH} 7.7$, containing $0.1 \mathrm{~mm}$ EGTA. To normalize the protein concentration in the samples, the homogenate of brain and thoracic ganglia was diluted. The NO synthase activity was determined by the conversion of oxyhemoglobin to methemoglobin by nitric oxide (Feelisch and Noak, 1987; Murphy et al., 1991; Mayer et al., 1992). The oxyhemoglobin was always freshly prepared as described (Feelisch and Noack, 1987). Immediately after homogenization, $30 \mu \mathrm{l}$ of the equivalent homogenate was mixed with $70 \mu \mathrm{l}$ of $50 \mathrm{~mm}$ Tris- $\mathrm{HCl}, \mathrm{pH}$ 7.7 , containing $10 \mu \mathrm{M}$ oxyhemoglobin, $0.1 \mathrm{~mm} \beta$-NADPH, $0.1 \mu \mathrm{M}$ calmodulin, and $0.1 \mathrm{~mm}$ L-arginine, with either $1 \mathrm{~mm}$ EGTA or $0.2 \mathrm{~mm}$ $\mathrm{Ca}^{2+}$. Reactions wcre startcd by the addition of NADPH and performed at $27^{\circ} \mathrm{C}$. Additional control experiments in which $\beta$-NADPH and L-arginine were omitted from the reaction mixtures were also performed. The conversion of oxyhemoglobin to methemoglobin was monitored with a Pharmacia spectrophotometer or a modified Reader (SLT Labinstruments, Austria). The extinction difference between 401 and 411 $\mathrm{nm}$ was recorded using a $\Delta \epsilon$ of $19.7 \mathrm{~mm}^{-1} \mathrm{~cm}^{-1}$ (Feelisch and Noack, 1987), or in the presence of catalase and superoxide dismutase, the change of 577 versus $591 \mathrm{~nm}$ was recorded using a $\Delta \epsilon$ of $11.2 \mathrm{~mm}^{-1} \mathrm{~cm}^{-1}$ (Murphy et al., 1991). Standards of nitric oxide release were prepared as described by Feelisch and Noack (1987).
NADPH diaphorase assay. For quantification of the fixation-insensitive NADPH diaphorase activity that accounts for the staining in the whole-mounts, the following procedure was applied. Equal amounts of protein of cell homogenates (al, br, tg; $30 \mu \mathrm{l}$ each) was bound to nitrocellulose $(\mathrm{NC})$ filters $(5 \times 5 \mathrm{~mm})$. After washing with $50 \mathrm{~mm}$ Tris- $\mathrm{HCl}$, pH 7.7, containing $0.1 \mathrm{M} \mathrm{NaCl}$, the $\mathrm{NC}$ filter was incubated in the presence or absence of $4 \%$ paraformaldehyde for $10 \mathrm{~min}$. After another extensive washing, the NADPH diaphorase activity on the NC filter was determined by incubation with $50 \mathrm{~mm}$ Tris- $\mathrm{HCl}, \mathrm{pH} 7.7,0.1 \mathrm{~mm}$ nitro blue tetrazolium, and $0.1 \%$ Triton $\mathrm{X}-100$ at $30^{\circ} \mathrm{C}$ in the presence or absence of $100 \mu \mathrm{M} \beta-\mathrm{NADPH}$ for $2-4 \mathrm{hr}$. After termination of the reaction the $\mathrm{NC}$ filters were mounted and the formazan product was determined by scanning the NC filters with a color scanner (UMAX $\mathrm{UC} 840$ ) at $585 \mathrm{~nm}$. All procedures, with the exception of the staining reaction, were carried out at $4^{\circ} \mathrm{C}$. For quantitative determination of the NADPH diaphorase activity, conditions were adjusted to keep the reaction in the linear range.

Quantitation of NO synthase activity in viable cells. NO production of dissociated cells was measured with the oxyhemoglobin assay similar to procedures described by others for cell lines (Bredt et al., 1992) or cultured endothelial cells (Murphy et al., 1991). Before the measurement, dissociated cells of the various nervous tissues (al, br, tg) were washed with locust Ringer of the following composition (in mM): $\mathrm{NaCl}$, $180 ; \mathrm{MgCl}_{2}, 15 ; \mathrm{CaCl}_{2}, 2 ; \mathrm{KCl}, 10 ; \mathrm{HEPES}, 10 ; \mathrm{pH}$ 7.0. They were subsequently resuspended in Ringer containing $10 \mu \mathrm{M}$ oxyhemoglobin and seeded in microtiter plates at a density of 1400 cells in $100 \mu \mathrm{l}$ per well. The conversion of oxyhemoglobin to methemoglobin was monitored continuously as described above in the microtiter plates with a modified Reader (SLT Labinstruments, Austria). To block calcium stimulation, incubations were performed as follows. Immediately before measuring the dissociated cells were split in half. One half was washed and resuspended in normal locust Ringer containing oxyhemoglobin, whereas the other half was washed and resuspended with locust Ringer containing $\mathrm{Co}^{2+}$ instead of $\mathrm{Ca}^{2+}$. For the inhibition of the NO synthase, cells were dissociated and preincubated for $1 \mathrm{hr}$ in locust Ringer containing $1 \mathrm{mM} \mathrm{N} \mathrm{N}^{\mathrm{G}}$-monomethyl-L-arginine or $\mathrm{N}^{\mathrm{G}}$-nitro-L-arginine. The conversion of oxyhemoglobin after adding the various agents was recorded for $60 \mathrm{~min}$ and compared to the photometric signal before stimulation. The difference in the signals was normalized with respect to control wells measured in each cell preparation.

To determine the possible interference of the agents and buffers used on the oxyhemoglobin assay, all substances were tested in control experiments with or without cell homogenates or viable cells, respectively. The locust Ringer as well as the used agents, like $\mathrm{A} 23187(10 \mu \mathrm{M}), \mathrm{Co}^{2+}$ $(2 \mathrm{mM})$, and acetylcholine $(3 \mu \mathrm{M})$, have no effect on the loss of oxyhemoglobin or the conversion of oxyhemoglobin to methemoglobin. Omission of catalase or superoxide dismutase in the assay mixture did not affect the NO production of cell homogenates or viable cells, respectively.

\section{Results}

\section{Histochemical detection of NADPHd}

NADPHd histochemistry was performed on whole-mounts of the cerebral, thoracic, and abdominal ganglia, from both adult and larval stages. NADPHd activity was detected in cell bodies and their neuropilar processes within the ganglia. Due to the easier penetration of the staining solution through the perineural sheath in larvae as compared to adult tissue, the following description is based on the examination of larval stages $3-5$, which gave the most satisfying histological results. Despite some differences in the staining intensity of neuropilar processes, there were no differences in the pattern of the cell body staining between the larval and adult stages. It should be stressed, however, that certain identifiable groups of somata consistently expressed a different intensity of staining than others in both larvae and adults.

In the cerebral ganglion, the most striking NADPHd activity was concentrated in a cluster of approximately 45 cell bodies in the dorsal region of the antennal lobe. As shown in Figure 1, the majority of stained cell bodies send their neurites into the 

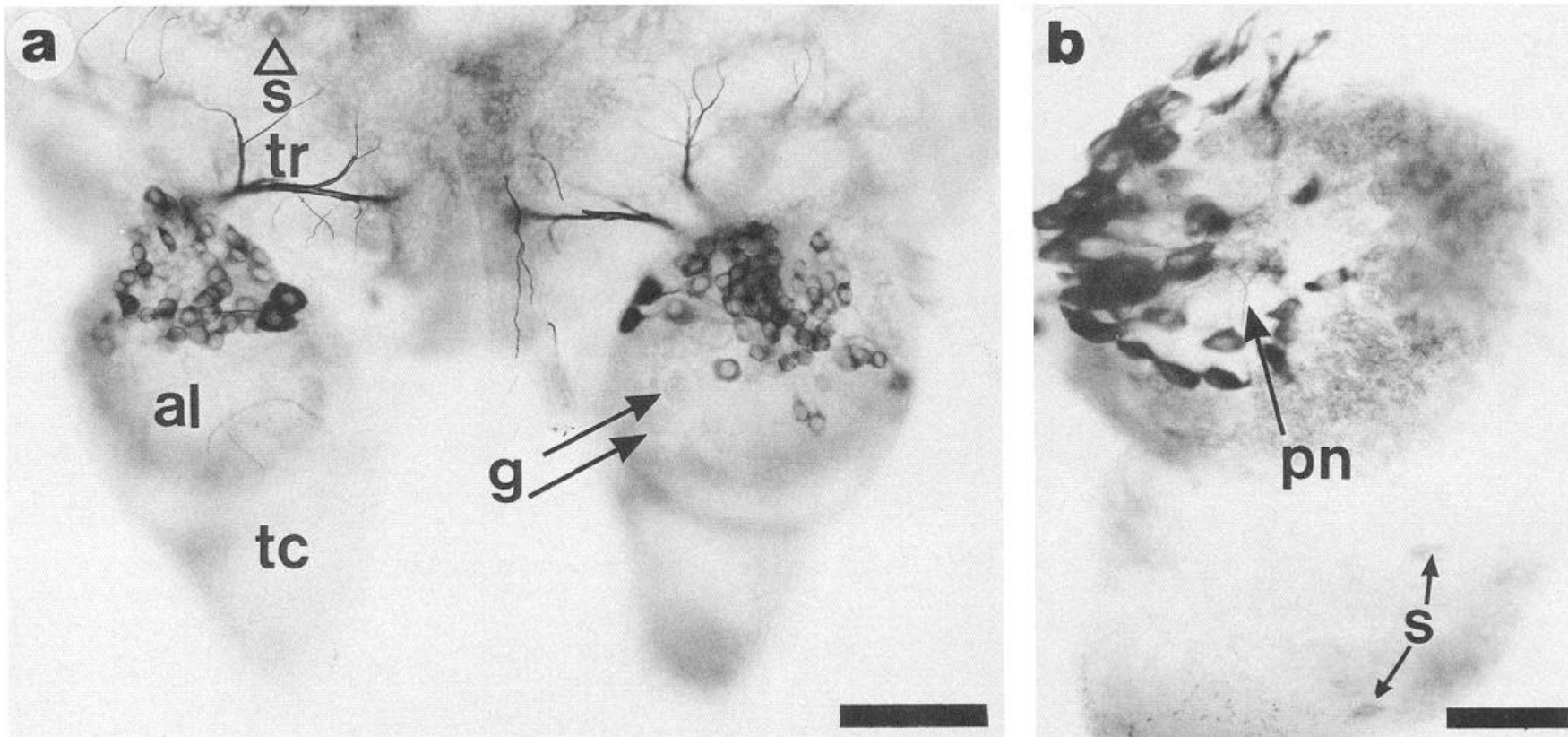

Figure 1. NADPHd histochemistry of the cerebral ganglion. $a$, Frontal view of a cerebral ganglion from larval stage 5 showing staining in cell bodies in the dorsal part of the antennal lobe $(\mathrm{al})$ and in the glomeruli $(\mathrm{g})$. The triangle indicates a soma $(s)$ belonging to a group of neurosecretory cells. Light-refracting structures are tracheae $(t r)$. Tritocerebrum $(t c)$ is positioned out of the focal plane. $b$, Frontal view of the deuto- and tritocerebrum from larval stage 3 showing primary neurites $(p n)$ of antennal lobe neurons entering the stained neuropil of the antennal lobe. Two stained somata $(s)$ are indicated in the tritocerebrum. Scale bars: $A, 200 \mu \mathrm{m} ; B, 100 \mu \mathrm{m}$.

\section{a}

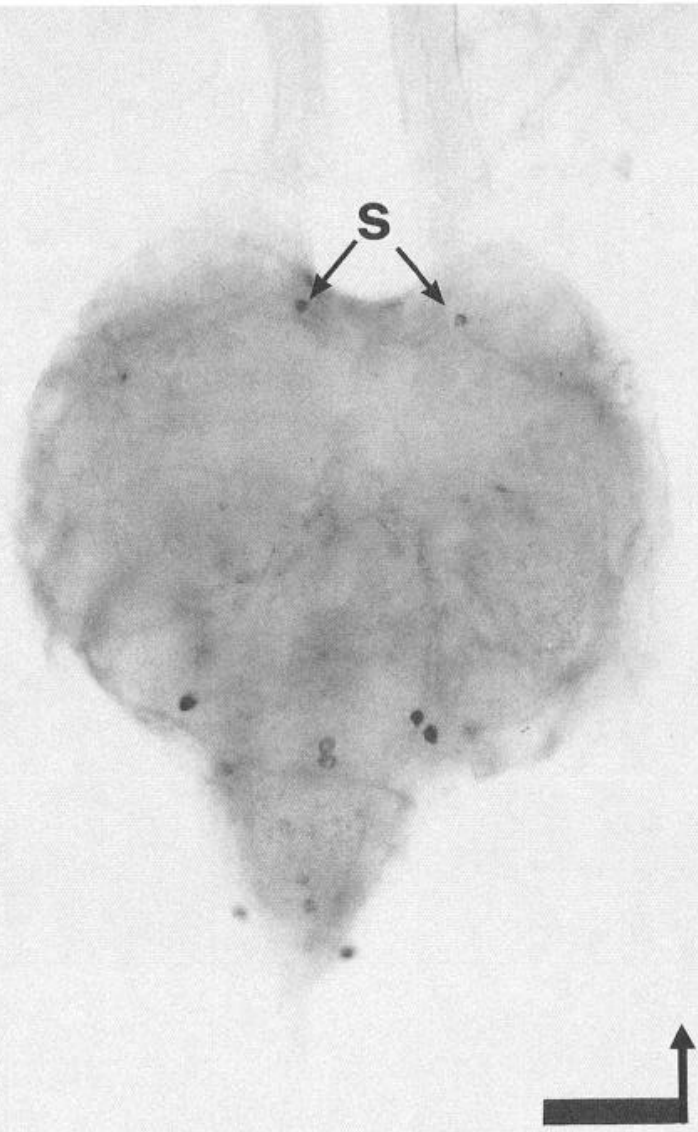

a

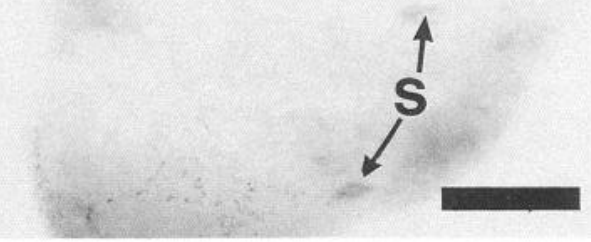

10

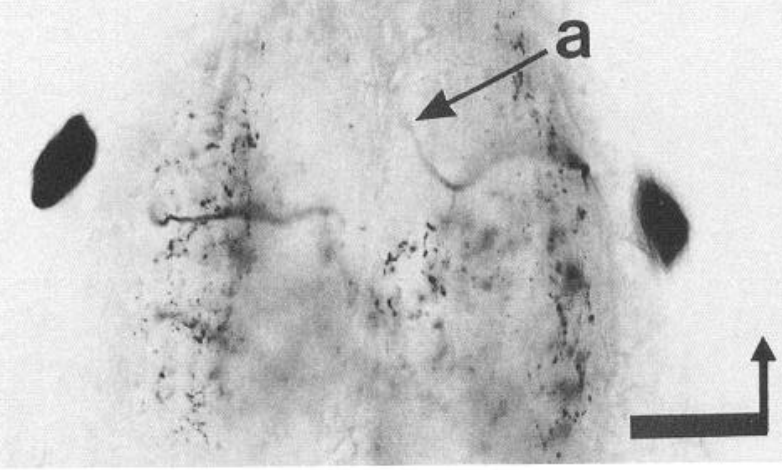

6

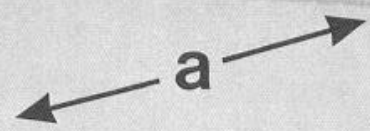

Figure 2. NADPHd histochemistry in the ventral nerve cord. $a$, Dorsal view of metathoracic ganglion of adult animal showing two stained somata $(s)$ at the entrance of the connectives and cell bodies in various other locations. Arrow points toward anterior. $b$, Anterior region of abdominal ganglion 7 of adult animal showing stained pair of neurons with ascending axon $(a)$ and varicose arborizations in portions of neuropil. Arrow points toward anterior. $c$, Connective between abdominal ganglion 7 and 6 showing two stained axons $(a)$ in the plane of focus. Scale bars, $200 \mu \mathrm{m}$. 

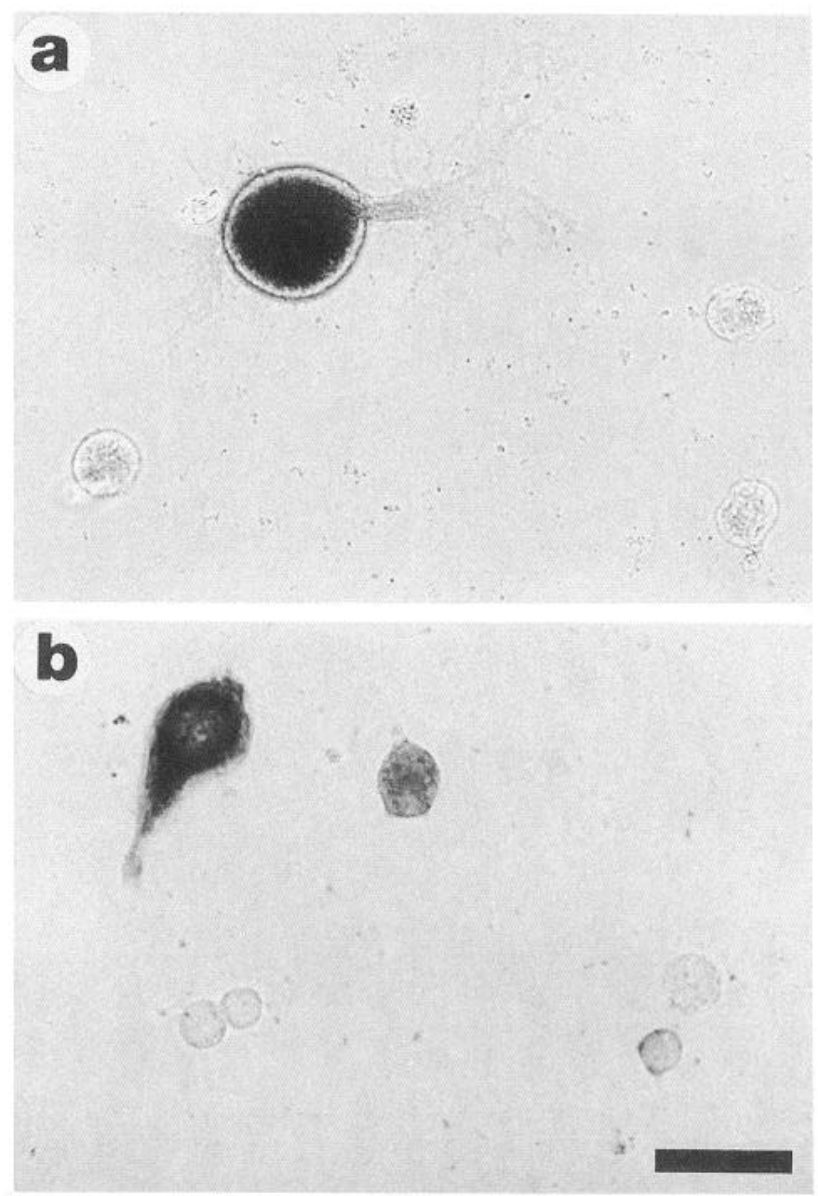

Figure 3. NADPHd histochemistry in vitro. $a$, Dissociated cells from the cerebral ganglion were stained after 1 week of primary culture. The transillumination reveals NADPHd expression in the cell body and regenerated neurites of a single cell. $b$, Histochemistry performed within hours after dissociation showing different staining intensities in the cell bodies. Scale bar, $50 \mu \mathrm{m}$.

glomeruli of the antennal lobe. Thus, the glomeruli contain a network of fine-grained arborizations originating from interneurons. Figure $1 b$ reveals the dense innervation from the NADPHd-positive soma group in the deutocerebral antennal lobe in contrast to a few scattered stained cell bodies and rather sparsely stained fibers in the tritocerebrum. No specific staining was detected in the antennal nerve, as has been reported in Drosophila and Apis (Müller and Buchner, 1993; Müller, 1994).

In the protocerebrum slight staining was also found in the lobes of the mushroom bodies. Presumably, the neuropilar label originates from neurons extrinsic to the mushroom body as the somata of the intrinsic globuli cells in the calycal region were not stained. Neurosecretory cells of the pars intercebralis were stained with an intermediate intensity (Fig. 1a) and labeled cell bodies were also found in the remaining parts of the cerebral ganglion including the optic ganglia. The flat, spindle-shaped morphology of single stained cell bodies in several locations of the cerebral ganglion suggests that they are not neurons, but of glial origin.

Each of the thoracic and abdominal ganglia shows a distinct pattern of stained cells. The prothoracic ganglion contains a single bilateral, intensely labeled soma, ventral to the anterior entrance of the connective, and approximately 10 lightly stained

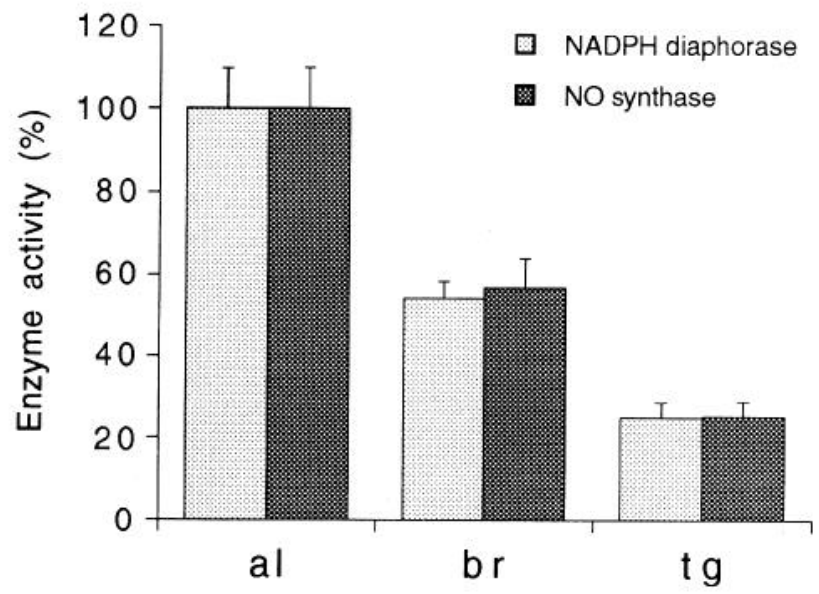

Figure 4. $\mathrm{Ca}^{2+} /$ calmodulin-dependent NO synthase activity and fixation-insensitive NADPH diaphorase activities in homogenates of cells from antennal lobes $(\mathrm{al})$, brain $(\mathrm{br})$, and thoracic ganglia $(\mathrm{tg})$, respectively. Equal amounts of protein from homogenates of the dissociated cells were compared. Each column shows the means \pm SEM of at least four separate experiments. The data were normalized with respect to the highest activities.

somata in a more lateral position. Similarly, an intensely stained soma was found close to the entrance of the connective in the meso- and metathoracic ganglia (Fig. 2a), suggesting a segmentally repeated organization. Approximately 20 stained cell bodies were found in other ganglionic locations in the second and third thoracic ganglion. According to Goodman and Bate (1981), each thoracic ganglion contains about 3000 somata. Thus, the NADPHd-positive cells constitute less than $1 \%$ of the population of neurons in the ventral nerve cord.

The whole-mount histochemistry revealed clearly the differential staining of thoracic and abdominal neurons (Fig. 2a,b), their varicose innervation of large portions of the neuropil (Fig. $2 b$ ), and intersegmentally projecting axons in the connectives (Fig. 2c). Despite the fact that viscera, neurohemal, and genital organs were ensheathed by NADPHd-positive non-neural cells (data not shown), we could not detect staining of motor or sensory axons in the thoracic and abdominal nerve roots.

Due to the smaller number of cells, identifiable neurons could be most easily detected in the unfused abdominal ganglia and the terminal ganglion. For example, in both females and males the abdominal ganglion AG 7 contains a symmetrical pair of neurons (Fig. $2 b$ ) whose ascending axons cross to the contralateral side of the ganglion before projecting anteriorly (Fig $2 c$ ).

\section{Histochemical detection of NADPHd in cell cultures}

Dissociated cell cultures provide a powerful system for studying the chemistry of neurons in a controlled environment, and locust neurons grown in primary cell culture have been shown to retain markers related to their transmitter metabolism (Kirchhof and Bicker, 1992). We cultured dissociated cells of the cerebral ganglion for 1 week to allow for neurite outgrowth and applied the NADPHd staining protocol after fixation. The culture dishes contained 3.5\% NADPHd-positive cells that expressed the label both in the cell body and in the regenerated neurites (Fig. $3 a$ ). Furthermore, NADPHd-positive somata could also be detected immediately after the dissociation process (Fig. $3 b$ ). 


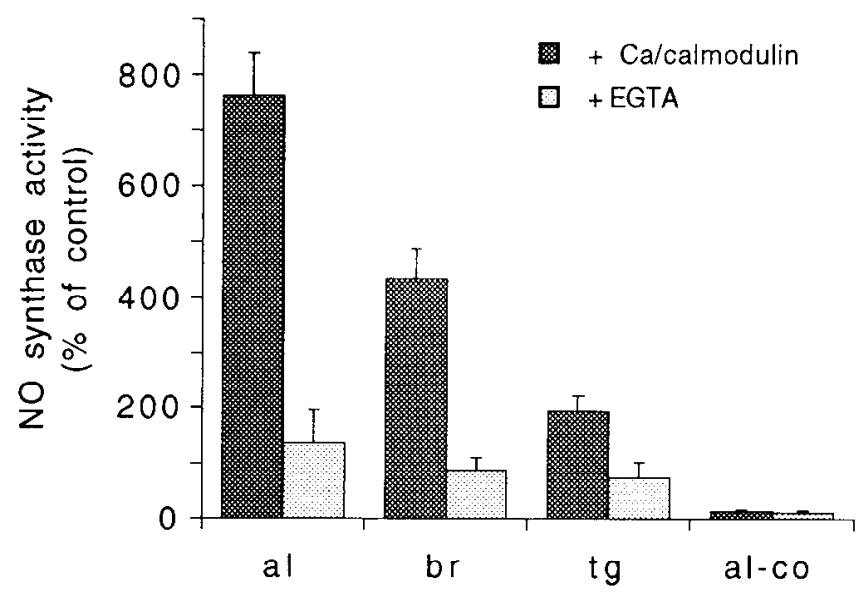

Figure 5. NO synthase activity in homogenates obtained from the antennal lobes $(a l)$, brain $(b r)$, and thoracic ganglia $(t g)$. The antennal lobe-control $(a l-c o)$ column shows results from antennal lobe cell homogenates that were incubated in reaction mixtures without $\beta$-NADPH and L-arginine. The $\mathrm{Ca}^{2+} /$ calmodulin-stimulated NO synthase activities were determined in equal amounts of protein from cell homogenates. Since the NO synthasc activities in nonstimulated (EGTA) cell homogenates from al, br, and tg show similar levels, the data were normalized with respect to the average of all EGTA controls. Each column shows the means \pm SEM of at least five separate experiments. All the data from stimulated and unstimulated homogenates are significantly different ( $p<0.01$, Student's $t$ test, two tailed).

\section{Neurochemical detection of NADPHd and NO synthase}

Thc histochemical staining for NADPHd in whole-mounts and isolated cells supports the existence of an NO messenger system in the locust. To strengthen the evidence that $\mathrm{Ca}^{2+} /$ calmodulindependent NO synthase is responsible for the histochemical staining in fixed nervous tissue of insects (Müller, 1994), we subjected dissociated cells from specific parts of the locust CNS to a biochemical analysis. These parts included the antennal lobes (al), the central brain comprising cerebral ganglion without optic and antennal lobes (br), and the three thoracic ganglia (tg). The cells were homogenized and equal amounts of protein were compared for NO synthase and NADPHd activity. NO synthase activity was determined by the conversion of oxyhemoglobin to methemoglobin (Feelisch and Noak, 1987; Murphy et al., 1991; Mayer et al., 1992). Because the histochemical staining was performed on fixed tissue, NADPH diaphorase activity was quantified after blotting the cell homogenates to nitrocellulose in the presence of fixativc. After normalizing to the maximal values, both enzyme activities showed an almost perfect correlation (Fig. 4), with the highest activities in the antennal lobe, intermediate in the central brain, and lowest in the thoracic ganglia. To this end, the biochemical measurements of enzyme activities (Fig. 4) demonstrated the tissue-specific expression of NO synthase and fixation-insensitive NADPHd that corresponds well to the histochemical staining (Figs. 1, 2).

To determine the $\mathrm{Ca}^{2+}$ dependence of enzyme activity, we measured NO formation in the cell homogenates in the presence and absence of $\mathrm{Ca}^{2+} /$ calmodulin stimulation. Again, cell homogenates prepared from the antennal lobes showed the highest activity, with an eightfold stimulation over basal levels (Fig. 5). Enzyme activities from the central brain were in the intermediate range, whereas the thoracic ganglia showed the lowest levels of inducible activity, which were nevertheless still sig-

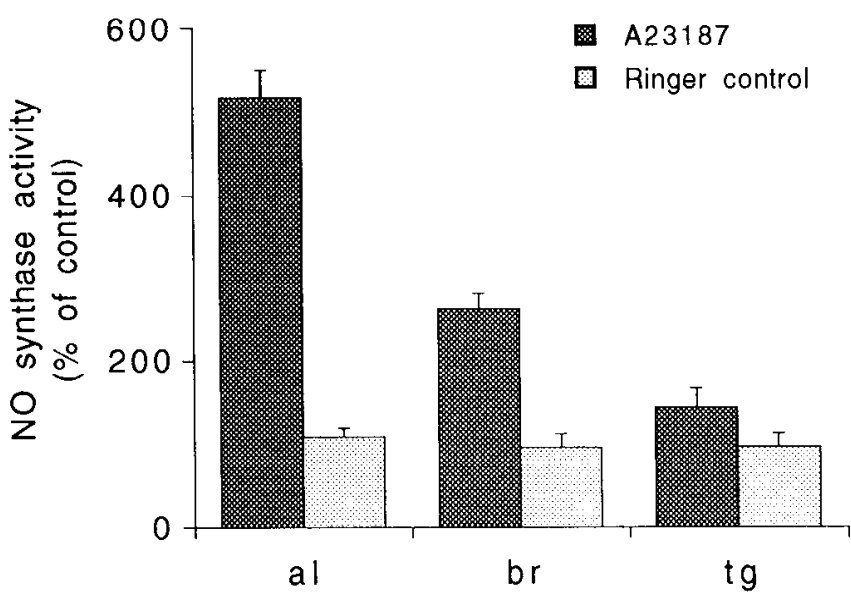

Figure 6. Stimulation of NO synthase activity in dissociated intact cells obtained from the antennal lobes $(a l)$, brain $(b r)$, and thoracic ganglia $(t g)$ by treatment with the $\mathrm{Ca}^{2+}$ ionophore $\mathrm{A} 23187(5 \mu \mathrm{M})$. Since the basal enzyme activity in the untreated cells is similar, the data were normalized with respect to the average of all Ringer controls. Each column shows the means \pm SEM of at least four separate experiments. The data from stimulated and unstimulated cells are significantly different ( $p<0.01$, Student's $t$ test, two tailed), with the exception of the thoracic ganglia $(\mathrm{tg})$.

nificantly different from controls in the absence of calcium (Fig. 5).

\section{Release of NO by dissociated neurons}

The histochemical demonstration of NADPHd expression in dissociated neurons prompted us to explore a direct on-line measurement of NO release from viable cells with the oxyhemoglobin assay (Feelisch and Noak, 1987; Murphy et al., 1991; Mayer et al., 1992). After dissociation cells were seeded in the presence of oxyhemoglobin into the wells of an ELISA plate and challenged with the $\mathrm{Ca}^{2+}$ ionophore A23187. Elevating cytoplasmic $\mathrm{Ca}^{2+}$ levels by the ionophore caused a fivefold increase of NO synthase activity in antennal lobe cells and a twofold increase over basal levels in cells from the central brain (Fig. 6). The $\mathrm{Ca}^{2+}$-induced NO production by thoracic cells was not significantly different from the unstimulated control and, given the limited cell density, presumably was at the detection threshold of the assay. However, a comparison of the NO synthase activity in homogenates (Fig. 5) and the corresponding viable cells (Fig. 6) reveals both the tissue-specific distribution and the $\mathrm{Ca}^{2+}$ dependence of the enzyme.

A basic requirement for identifying $\mathrm{NO}$ as a messenger molecule is the calcium-dependent release after depolarization of viable cells. Therefore, we challenged the dissociated cells with depolarizing agents in the presence and absence of extracellular $\mathrm{Ca}^{2+}$. As with treatment with the $\mathrm{Ca}^{2+}$ ionophore, depolarizing the cells by the application of high $\mathrm{K}^{+}(30 \mathrm{mM} \mathrm{KCl})$ caused an increase in enzyme activity (Fig. 7). Replacing extracellular $\mathrm{Ca}^{2+}$ with $2 \mathrm{mM} \mathrm{Co}^{2+}$ reduced the activity below Ringer control levels. Dissociation and preincubation of cells in the presence of the NO synthase blocker nitroarginine prevented the $\mathrm{K}^{+}$-induced increase, demonstrating a specific inhibitory action on NO synthase. To mimic more physiological conditions, we applied acetylcholine (ACh), which is thought to act predominantly as an excitatory neurotransmitter in the insect nervous system (Breer, 1987). ACh caused a stimulation of enzyme activity, suggesting 


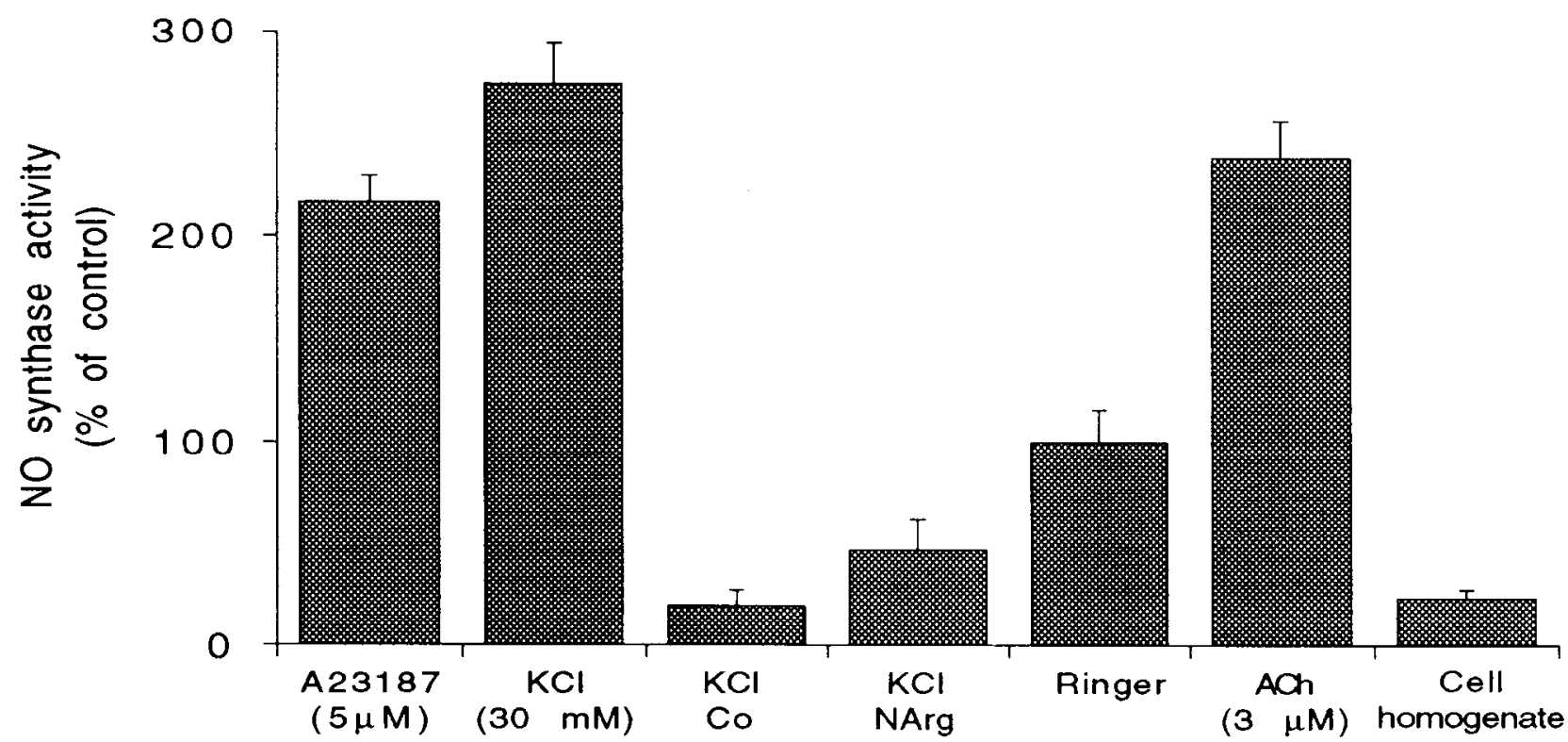

Figure 7. Regulation of $\mathrm{NO}$ synthase activity in dissociated cells from the cerebral ganglion by elevation of cytoplasmic $\mathrm{Ca}^{2+}$ levels. The cells were stimulated with the $\mathrm{Ca}^{2+}$ ionophore $\mathrm{A} 23187(5 \mu \mathrm{M}), \mathrm{KCl}(30 \mathrm{mM})$, and $\mathrm{ACh}(3 \mu \mathrm{M})$. Increase of activity was blocked by replacing extracellular $\mathrm{Ca}^{2+}$ with $\mathrm{Co}^{2+}(\mathrm{KClCo})$, or by pretreatment with $1 \mathrm{~mm}$ of the NO synthase inhibitor nitroarginine $(\mathrm{KClNArg})$. Parallel treatment of cell homogenates with $\mathrm{Ca}^{2+}$ ionophore, $\mathrm{KCl}$, and $\mathrm{ACh}$ does not activate $\mathrm{NO}$ synthase since cofactors and cosubstrates are missing. The data were normalized with respect to the average of Ringer controls. Each column shows the means \pm SEM of at least eight separate experiments.

that neurotransmitter stimulation is sufficient to release NO in vivo. Finally, to rule out unspecific artifacts of cell damage that might not require $\mathrm{Ca}^{2+}$ influx into intact cells, we exposed cell homogenates to the agents, but failed to induce any enzyme activity. Since the assay did not contain any cofactors or cosubstrates of NO synthase, NO production depends on intact cells.

\section{Discussion}

The mechanisms by which nerve cells release transmitters and other signaling molecules are as fundamental to neurobiology as are the mechanisms by which these same messengers interact with their target receptors. Based on NADPHd histochemistry (Müller and Buchner, 1993; Müller, 1994) and biochemical measurement of NO synthase activity in homogenates (Elphick et al., 1993) nitric oxide is a candidate messenger in the nervous system of fruit flies, bees, and locusts. NADPH diaphorasepositive neurons have recently also been described in several nonarthropod invertebrate phyla (Elofsson et al., 1993). However, the actual demonstration of $\mathrm{NO}$ release from invertcbratc nerve cells has so far not been obtained. One of the principal identification criteria for a neurotransmitter is its $\mathrm{Ca}^{2+}$-dependent release during nerve cell depolarization (Werman, 1966). Analogous criteria should be met for the activity-dependent release of any type of signaling molecule in the nervous system. In practice, however, the accurate chemical detection of a $\mathrm{Ca}^{2+}$ dependent release from intact nerve cells is difficult to prove for transmitter identification. In most cases it is experimentally performed on synaptosomes, perfused brain slices, or peripheral glandular and neuromuscular preparations. This experimental obstacle applies especially to the detection of an extremely reactive compound such as nitric oxide (Stamler et al., 1993).

Initially we set out to identify candidate NO-releasing cells by simple NADPHd whole-mount histochemistry. The anatomical screening revealed less than 1\% NADPHd-positive cells in the ventral nerve cord (Fig. 2), but a group of 45 intensely stained cells in the antennal lobe (Fig. 1) of the cerebral ganglion. The cerebral ganglion of the locust proved ideal to analyze NO release because of a rather high portion of candidate NO-synthesizing neurons and the ease of establishing viable dissociated cells that preserved the NADPHd phenotype (Fig. 3).

This finding allowed the chemical detection of NO release from dissociated neurons by the conversion of oxyhemoglobin to methemoglobin. The spectrophotometric assay has already been used to measure NO production by cultured endothelial cells after stimulation with the $\mathrm{Ca}^{2+}$ ionophore A23187 (Murphy et al., 1991). NO is synthesized by a $\mathrm{Ca}^{2+} /$ calmodulinstimulated enzyme (Garthwaite, 1991; Bredt and Snyder, 1992), which proved to be $\mathrm{Ca}^{2+}$ dependent in homogenates (Fig. 5). Therefore, the following experiments provided strong arguments for interpreting the changes of the photometric signal in the oxyhemoglobin assay on intact cells as released NO that binds to the heme group. Significant changes were detected only after adding agents to the incubation medium that are known to clevate cytoplasmic $\mathrm{Ca}^{2+}$ levels (Figs. 6, 7). A signal was generated by membrane depolarization with $\mathrm{KCl}$, which causes $\mathrm{Ca}^{2+}$ influx via voltage-operated calcium channels and by direct calcium influx via an ionophore. Replacing extracellular $\mathrm{Ca}^{2+}$ by cobalt reduced the signal below Ringer control levels. Acetylcholine is one of the main excitatory neurotransmitters of the insect nervous system (Breer, 1987) and recent $\mathrm{Ca}^{2+}$ imaging experiments have indeed shown that $\mathrm{ACh}$ induces elevation of cytoplasmic calcium levels in neurons of an insect brain (Bicker and Kreissl, 1994). Again, treatment of dissociated locust neurons with $\mathrm{ACh}$ in the micromolar range caused a photometric signal, presumably by activating NO synthase via an influx of $\mathrm{Ca}^{2+}$, mainly through voltage-operated calcium channels. Highvoltage-activated $\mathrm{Ca}^{2+}$ currents have also been demonstrated in isolated locust neurons (Pearson et al., 1993). All our reported experiments argue strongly for $\mathrm{a} \mathrm{Ca}^{2+}$-dependent process in the 
generation of the photometric signal. We interpret the remaining signal in the Ringer control as NO that is continuously released during the assay. Application of the NO synthase blocker $n$-arginine caused a reduction of the $\mathrm{KCl}$-induced signal to levels comparable to the cobalt block. This is in agreement with experiments demonstrating the effectiveness of $n$-arginine as inhibitor of NO synthase in homogenates of locust (Elphick et al., 1993) and other insect nervous tissue (Müller, 1994). The combined results are consistent with the hypothesis that at least the proportion of the $n$-arginine-blocked signal represents NO that is released by cells of the locust nervous system in a $\mathrm{Ca}^{2+}$ dependent process.

The photometric detection of NO synthase activity of dissociated neurons taken from the brain, the antennal lobe, and the thoracic ganglia (Fig. 6) correlated well to the histochemically mapped distribution of NADPHd-positive cell bodies in situ (Figs. 1, 2). Furthermore, the ratio of NADPd and NO synthase activity in cell homogenates (Fig. 4) indicated the identity of the enzyme in the CNS of the locust, as has been shown for vertebrates (Dawson et al., 1991; Hope et al., 1991; Matsumoto et al., 1993) and for Drosophila and Apis (Müller, 1994). We suggest that in the locust nervous system the expression of NADPHd activity after fixation is equivalent to NO synthase. Therefore, we feel confident that the organization of the release sites of the NO signal transduction system can be derived from the NADPHd staining pattern.

The hallmark of the NADPHd histochemistry in the brain is the concentration of NADPHd-positive neurons in the olfactory neuropil of the antennal lobe. Despite some differences in the anatomical distribution of NADPHd activity in the brains of Drosophila and Apis, the most intense staining was also expressed in neuropils associated with olfactory pathways (Müller, 1994). The association of NO synthase with the antennal lobe (Müller and Buchner, 1993; Müller, 1994) and olfactory bulb (Bredt and Snyder, 1992; Vincent and Kimura, 1992) seems to be common to insects and vertebrates.

Due to an inhibition of endogenous guanylyl cyclase by high intracellular calcium concentrations, NO raises cGMP concentrations in neighboring cells and is therefore thought to act as a transsynaptic messenger molecule (Garthwaite, 1991; Bredt and Snyder, 1992). Breer and Shepherd (1993) pointed out that in the olfactory system the NO/cGMP system might mediate lateral interactions between dendrites in the glomeruli of the olfactory bulb, which are ideally suited to act as a diffusion barrier. A synaptically activated release of NO from the NADPHd-positive arborizations in the glomeruli of the antennal lobe may perform a similar function in the insect CNS and influence sensory integration by increasing cGMP levels in neighboring cells.

Some conclusion can also be drawn from the anatomical data in the ventral nerve cord. A variety of conventional neurotransmitter systems have been described in the thoracic and abdominal ganglia, mainly by immunocytochemical methods. These include cholinergic (Breer, 1987; Lutz and Tyrer, 1987), GABAergic (Watson, 1986; Watson and Burrows, 1987; Watson and Pflüger, 1987), glutamatergic (Bicker et al., 1988; Watson, 1988; Watson and Seymour-Laurent, 1993), serotonergic (Taghert and Goodman, 1984; Tyrer et al., 1984), dopaminergic(Watson, 1992), and octopaminergic (Evans and O'Shea, 1978; Konings et al., 1988; Stevenson et al., 1992) pathways. Our description, based on whole-mount histochemistry, indicates that NO-releasing neurons show hardly any colocalization with the conventional transmitters but constitute a new separate signaling pathway.

Since NADPHd activity could be detected in the neuropils (Fig. $2 b$ ) and connectives (Fig. 2c) of the ventral ganglia, but not in the peripheral nerves, NO is produced only by interneurons but not by moto- and sensory neurons. With the caveat that some neurons, for example, dorsal unpaired median (DUM) cells (Hoyle et al., 1974; Evans and O'Shea, 1978), have very thin peripherally projecting neurites, which may be difficult to resolve in simple histological staining procedures, we propose that NO acts mainly as a signaling molecule in the central parts of the locust ventral nerve cord.

This study has been concerned only with the $\mathrm{Ca}^{2+}$-activated release of NO, but it is obviously desirable to address the responses of the cellular targets in the CNS to the endogenously produced messenger molecule. Since locust neurons can be readily grown in primary culture, the various signal transduction mechanisms of NO in elevating cGMP levels in target cells (Garthwaite, 1991; Bredt and Snyder, 1992), as modifier of synaptic efficacy (Zhuo et al., 1993), as regulator of neurite growth (Hess et al., 1993), and as neurotoxic or neuroprotective agent (Lipton et al., 1993), will also be amenable to a cellular analysis. Ultimately, locusts could provide useful preparations in which release and effect of $\mathrm{NO}$ can be studied in an accessible invertebrate nervous system at the level of single identified neurons.

\section{References}

Bicker G, Kreissl S (1994) Calcium imaging reveals nicotinic acetylcholine receptors on cultured mushroom body neurons. J Neurophysiol 71:808-810.

Bicker G, Schäfer S, Ottersen OP, Storm-Mathisen J (1988) Glutamate-like immunoreactivity in identified neuronal populations of insect nervous systems. J Neurosci 8:2108-2122.

Bredt DS, Snyder SII (1992) Nitric oxide, a novel neuronal messenger. Neuron 8:3-11.

Breer H (1987) Neurochemical aspects of cholinergic synapses in the insect brain. In: Arthropod brain: its evolution, development, structure and function (Gupta AP, ed), pp 415-438. New York: Wiley.

Breer H, Shepherd GM (1993) Implications of the NO/cGMP system for olfaction. Trends Neurosci 16:5-9.

Dawson TM, Bredt DS, Fotuhi M, Hwang PM, Snyder SH (1991) Nitric oxide synthase and neuronal NADPH diaphorase are identical in brain and peripheral tissues. Proc Natl Acad Sci USA 88:77977801 .

Elofsson R, Carlberg M, Moroz L, Nezlin L, Sakharov D (1993) Is nitric oxide (NO) produced by invertebrate neurones? Neuroreport 4:279-282.

Elphick MR, Green IC, O'Shea M (1993) Nitric oxide synthesis and action in an invertebrate brain. Brain Res 619:344-346.

Evans PD, O'Shea M (1978) The identification of an octopaminergic neurone and the modulation of a myogenic rhythm in the locust. $J$ Exp Biol 73:235-260.

Feelisch M, Noak EA (1987) Correlation between nitric oxide formation during degradation of organic nitrates and activation of guanylate cyclase. Eur J Pharmacol 139:19-30.

Garthwaite J (1991) Glutamate, nitric oxide and cell-cell signalling in the nervous system. Trends Neurosci 14:60-67.

Giles DP, Usherwood PNR (1985) Locust nymphal neurones in culture: a new technique for studying the physiology and pharmacology of insect central neurones. Comp Biochem Physiol [C] 80:53-59.

Goodman CS, Bate CM (1981) Neuronal development in the grasshopper. Trends Neurosci 4:163-169.

Hope BT, Michael GJ, Knigge KM, Vincent SR (1991) Neuronal NADPH diaphorase is a nitric oxide synthase. Proc Natl Acad Sci USA 88:2811-2814.

Hoyle G (1974) A function for neurons (DUM) neurosecretory on skeletal muscle of insects. J Exp Zool 189:401-406.

Kirchhof B, Bicker $G$ (1992) Growth properties of larval and adult locust neurons in primary cell culture. J Comp Neurol 323:41 1-422. 
Konings PNM, Vullings HGB, Geffard M, Buijs RM, Diederen JHB, Jansen WF (1988) Immunocytochemical demonstration of octopamine-immunoreactive cells in the nervous system of Locusta migratoria and Schistocerca gregaria. Cell Tissue Res 251:371-379.

Lipton SA, Choi Y-B, Pan Z-H, Lei SZ, Chen H-SV, Sucher NJ, Loscalzo J, Singel DJ, Stamler JS (1993) A redox-based mechanism for the neuroprotective and neurodestructive effects of nitric oxide and related nitroso-compounds. Nature 364:626-632.

Lutz EM, Tyrer NM (1987) Immunohistochemical localization of choline acetyltransferase in the central nervous system of the locust. Brain Res 407:173-179.

Matsumoto T, Nakanc M, Pollock JS, Kuk JE, Fürstcrmann U (1993) A correlation between soluble brain nitric oxide synthase and NADPHdiaphorase activity is only seen after exposure of the tissue to fixative. Neurosci Lett 155:61-64.

Mayer B, Klatt P, Böhme E, Schmidt K (1992) Regulation of neuronal nitric oxide and cyclic GMP formation by $\mathrm{Ca}^{2+}$. J Neurochem 59 : 2024-2029.

Müller U (1994) $\mathrm{Ca}^{2+} /$ calmodulin dependent nitric oxide synthase in Apis mellifera and Drosophila melanogaster. Eur J Neurosci, in press.

Müller U, Buchner E (1993) Histochemical localization of NADPHdiaphorase in adult Drosophila brain: is nitric oxide a neuronal messenger also in insects? Naturwissenschaften 80:524-526.

Murphy ME, Piper HM, Watanabe H, Sies H (1991) Nitric oxide production by cultured aortic endothelial cells in response to thiol depletion and replenishment. J Biol Chem 266:19378-19383.

Pearson HA, Lees G, Wray D (1993) Calcium channel currents in neurones from locust (Schistocerca gregaria) thoracic ganglia. J Exp Biol 177:201-221.

Stamler JS, Singel DJ, Loscalco J (1992) Biochemistry of nitric oxide and its redox-activated forms. Science 258:1898-1902.

Stevenson PA, Pflüger H-J, Eckert M, Rapus J (1992) Octopamine immunoreactive cell populations in the locust thoracic-abdominal nervous system. J Comp Neurol 315:382-397.

Stuehr DJ, Griffith OW (1992) Mammalian nitric oxide synthases. Adv Enzymol 65:287-346.
Stuehr DJ, Kwon NS, Nathan CF, Griffith OW, Feldman PL, Wiseman $\mathrm{J}$ (1991) $N^{\omega}$-hydroxy-L-arginine is an intermediate in the biosynthesis of nitric oxide from L-arginine. J Biol Chem 266:6259-6263.

Taghert PH, Goodman CS (1984) Cell determination and differentiation of identified serotonin-immunoreactive neurons in the grasshopper embryo. J Neurosci 4:989-1000.

Tyrer NM, Turner JD, Altman JS (1984) Identifiable neurons in the locust central nervous system that react with antibodies to serotonin. J Comp Neurol 227:313-330.

Vincent SR, Kimura H (1992) Histochemical mapping of nitric oxide synthase in the rat brain. Neuroscience 46:755-784.

Watson AHD (1986) The distribution of GABA-like immunoreactivity in the thoracic nervous system of the locust Schistocerca gregaria. Cell Tissue Res 246:331-341.

Watson AHD (1988) Antibodies against GABA and glutamate label neurons with morphologically distinct synaptic vesicles in the locust central nervous system. Neuroscience 26:33-44.

Watson AHD (1992) The distribution of dopamine-like immunoreactivity in the thoracic and abdominal ganglia of the locust (Schistocerca gregaria). Cell Tissue Res 270:113-124.

Watson AHD, Burrows M (1987) Immunocytochemical and pharmacological evidence for GABAergic spiking local interneurones in the locust. J Neurosci 7:1741-1751.

Watson AHD, Pflüger H-J (1987) The distribution of GABA-like reactivity in relation to ganglion structure in the abdominal nerve cord of the locust (Schistocerca gregaria). Cell Tissue Res 249:391402

Watson AHD, Seymour-Laurent (1993) The distribution of glutamatelike immunoreactivity in the thoracic and abdominal ganglia of the locust (Schistocerca gregaria). Cell Tissue Res 273:557-570.

Werman R (1966) Criteria for identification of a central nervous system transmitter. Comp Biochem Physiol 18:745-766.

Zhuo M, Small SA, Kandel ER, Hawkins RD (1993) Nitric oxide and carbon monoxide produce activity-dependent long-term synaptic enhancement in hippocampus. Science 260:1946-1950. 